 \\ Law
}

\section{JOHN MCELDOWNEY}

This chapter offers a legal perspective on democratization by focusing on a tightly linked set of issues straddling the border between political and judicial power as they have arisen in, first, the United Kingdom, second, Britain's relationship with the European Union, and third, the wider international system. The discussion illustrates the claim that no analysis of democratization can be complete without taking into account the dimension of judicial power and its implications for democratic accountability even, perhaps especially, in countries considered as exemplars for new and emerging democracies. The development of strategies under the umbrella of legal technical assistance that seek to enhance the standing of political decision-makers while remaining compatible with the principle of judicial oversight poses perhaps one of the most important challenges for democratization in the present century.

Countries in the process of devising new institutions for a democratic political regime aiming to give enhanced legitimacy to the exercise of power have much to learn from the experience of their mentors in those Western democracies that have already undergone a significant incremental growth in judicial power (Sweet 2000). How far is judicial power compatible with democratic government? That key question will be addressed in the following way. First, the source and growth of judicial power in the Anglo-American tradition of jurisprudence will be outlined. Second, the United Kingdom's experience of adopting the Human Rights Act 1998 is discussed as an example of a potential shift from political decision-making to judge-made decisions, and this potential is assessed. ${ }^{1}$ Third, the growth of judicial 
decision-making within the European Union is considered as a further example of how judicial power is incrementally increasing. Fourth, the development of the international criminal court is noted as an example of how judicial power is increasingly seen as the means to ensure global standards for justice and the rule of law. Finally, following Loughlin (2001: 41), it is argued that over-reliance on the judicial element at the expense of democratic institutions sets a dangerous precedent as to who legitimates the legal order in society, and may undermine political and economic sovereignty. The lessons of Western democracies should not be lost on developing countries undergoing institutional reform.

\section{The judicial power in the Anglo-American tradition}

There is an active debate in the United States between those who consider that the role of the judges is to act as independent principals and those who see the judges as faithful agents interpreting the law according to the plain words in front of them (Eskridge 1994). The former adopt a purposive approach in which the courts are expected to carry forward into practice the aims and objectives of statutes and the interpretation of parliamentary intent. Judges are free to exercise an independent role in their decisionmaking. The latter see the judges as having a more restricted role defined by textual analysis, requiring judges to be dutifully bound to act within the limits of the statute. Judges are expected to undertake the task prescribed by law and within the narrow confines of decision-making to take account of the limits on judicial power and the constitution. There appears to be common ground between these perspectives: the role of the judicial power and how it is interpreted is called into question. In reviewing some of the historical evidence it is clear that judges from the earliest beginnings were prepared to go beyond the plain meaning of words and take account of extraneous material. In many instances this was a practical response to the problems of interpretation, and rarely did it seem to challenge the interests of the state. In the English common law this may have 
been because of the absence of any formal doctrine of the separation of powers; but it is more likely to have reflected a period before the development of a strong tradition of parliamentary sovereignty.

The history of the English common law is instructive as to how judicial power emerged through the centuries of royal power. Judges possessed widely drawn powers. The early commentators noted how the rules of statutory interpretation were developed on an eclectic basis. A common approach was to consider the canons of statutory construction around principles of 'equitable' construction. Textual analysis was accompanied by various techniques and methods of statutory construction. In the eighteenth century Blackstone's monumental Commentaries on the Laws of England demonstrated the wide range and diversity inherent in judicial discretion. The pragmatic qualities of the common law allowed the creativity of the judges to develop its own methodology of statutory construction. Various approaches to statutory interpretation developed in order to give effect to 'the natural' meaning of the words, and the 'will and intention of the legislator'. The fiction of the 'reasonable man' was frequently employed to set standards and direct outcomes. And in some instances the courts attempted to discover 'the mischief' that was behind the legislative enactment in order that the common law should provide a remedy. The early case law is rich in the adoption of modes of interpretation to fit the circumstances of the case. The revolution culminating in Parliament's victory over the Crown in the 'Glorious Revolution' (1688) came as the courts recognized the authority of parliament and its ultimate law-making authority. This provided the judges with the dominant paradigm of interpretation, which for centuries has been used to expound and explain Parliament's will and by so doing to give effect to judicial discretion. On the boundaries of law-making and judicial interpretation rests the key distinction between parliamentary and judicial power. The paradox was that, while the judges recognized Parliament's ultimate law-making authority, it was on their own authority that they articulated the nature of the parliamentary sovereignty that they recognized. In truth it was finely balanced as to whether ultimate judicial or Parliamentary authority might prevail. In the famous Dr Bonham's 
case (1609) Sir Edward Coke somewhat ambiguously suggested that the common law might 'controul Acts of Parliament and some times adjudge them to be utterly void: for when an Act of Parliament is against common right and reason or repugnant, or impossible to be performed, the common law will controul it, and adjudge such Act to be void' ${ }^{2}$

The idea of judges being capable of testing statutes to destruction if they were found to be against a fundamental principle of law raises the possibility for judicial power rather than parliamentary to sit at the apex of the constitution. However plausible this interpretation might appear, a more realistic assumption is that Sir Edward Coke believed that as far as it is practical it is necessary for the courts to try to give effect to the meaning of the statute that is consistent with parliamentary intention. This is the meaning accorded to Coke's verdict by Blackstone. Some observers might think that the ascendancy of Parliamentary authority is commensurate with a demise in judges closing loopholes and developing their own equitable solution beyond the true intention of Parliament. But this is barely plausible once the scale of judicial creativity is recognized. Keeping in mind that judges developed legal tests for the purposes of instructing and controlling the jury, it is by no means clear that the judiciary adopted a more limited role for their own authority. A far more compelling preoccupation for the judiciary throughout the eighteenth and nineteenth centuries was to develop contract law, through the insistence of the doctrine of freedom of contract and settling land disputes through the development of land law and equity.

The judges have continued to think of the common law as equivalent to a fundamental law capable of wide-scale judicial interpretation. Instances where the courts settled fundamental constitutional issues include the Case of Proclamations (1611), which claimed the common law as providing the courts with overarching powers of review. In 1839 the privileges of Parliament were settled in Stockdale v. Hansard (1839) where the courts articulated the jurisdiction of the courts to define parliamentary immunities and privileges.

The tradition of judicial innovation and creativity survives today. Scattered throughout the law reports are some glimpses of how proactive judges have become in an era of 
increasing judicial self-confidence. All the law relating to administrative law is judicially created and self-executed in terms of legal tests and criteria for the grounds for judicial review, the rules of standing and the remedies available to the claimant, culminating for the first time in the creation of an administrative court. The articulation of common law fundamentals may take a number of forms. The rule of law, a rhetorical term (much cited in political discussions of recent attempts at democratization around the world) has in the hands of the senior judiciary become a principle of legality. In the case of Entick v. Carrington (1765) it was held that the Secretary of State had no powers to issue a general warrant on the basis of state necessity. The absence of legal authority provided the opportunity for the courts to consider whether there had been a trespass that was a violation of property rights. More recently, Lord Nolan referred to the rule of law in $M v$. Home Office (1992) - a case involving deportation - as 'the submission of the executive to orders of the court' ${ }^{3}$ The courts have traditionally sought to uphold the rule of law and due process. Lord Bridge explained the importance of the rule of law in the context of the constitution as a whole: 'The maintenance of the rule of law is in every way as important in a free society as the democratic principle. In our society the rule of law rests upon twin functions: the sovereignty of the Queen in Parliament in making the law and the sovereignty of the Queen's courts in interpreting and applying the law. ${ }^{4}$

The creation of an enlarged administrative jurisdiction of the courts has been largely undertaken by the judges on their own as an attempt to keep pace with the desire of successive governments to change and modernize. Past practices and older legal interpretations are frequently revisited and re-interpreted in the light of modern experience. The rule of crown immunity, drawn from the idea that the 'king can do no wrong', has been replaced by the courts claiming inherent jurisdiction over government powers, including the use of the prerogative. The rule that no injunction may lie against the Crown has also been reconsidered in the light of current practice.

In terms of judicial powers and their relationship to the democratic principle, then, there is a dialogue between the courts, the legislature and the government of the day. In 
practical terms this has set the boundaries between judges and politicians. There is a similar dialogue in the United States as to how far judicial power should be self-executing and how far it is confined to textual analysis. In the United States in the landmark decision of Marbury v. Madison (1803) Chief Justice John Marshall applied a pragmatic approach by re-interpreting the statute, re-wrote the text and gave a new meaning to the law that departed from what was included by the original draftsman. Many of the early decisions of the United States Supreme Court follow the pattern of thinking evidenced in the development of the English common law. It is clear that rules or canons of statutory interpretation leave judges considerably empowered with the discretion as to how to develop and extend legal principles to do justice in the case in question. Many commentators see this as resting on liberal foundations that declare the courts independent from the state as guardians against oppression. Yet there appears to be little consistency or predictability. At times the US courts adopt a strict interpretation and appear highly restrictive. At other times the courts become more libertarian, and appear to fulfil the role of protecting the individual. In adopting either interpretation the courts have seen their authority continue with the boundaries between judicial and political power often ragged and unclear.

\section{The Human Rights Act 1998: a case study}

The Human Rights Act 1998 came into force in Britain on 2 October 2000. The Act provides a useful case study of how incorporation of the European Convention on Human Rights into domestic law of the United Kingdom may provide judges with greater discretion than hitherto. This has the obvious danger of shifting political decision-making to come within judicial power. The Act has provided opportunities for litigation and greater legal complexity in decisionmaking. There are ongoing lessons to be gained from this experience, and it is instructive for countries developing reforms through legal technical assistance from countries like Britain. 
The Human Rights Act 1998 significantly changed how rights are enjoyed in England and Wales, by incorporating for the first time into domestic law the main substance of the European Convention on Human Rights (ECHR) signed in 1950. This Convention provides rights such as freedom of expression and association; rights to privacy and information; and procedural protections for the individual in the areas of criminal, civil and administrative law. Under the ECHR, the European Court of Human Rights was set up to hear cases alleging breaches of Convention obligations. Owing to the high reputation of this court, the Convention is well known internationally for guaranteeing the citizen positive rights.

Uniquely amongst countries that ratified the ECHR in 1950, the United Kingdom failed to incorporate it into domestic law - even though the United Kingdom was the first country to sign it and British lawyers carried out most of the drafting. As the United Kingdom is a dualist state, it needed to incorporate the ECHR into domestic law to allow British citizens direct access to enforceable rights under the Convention in the British courts. From 1966 to the end of 1995 the United Kingdom found itself before the European Court of Human Rights on no less than sixty occasions (Gearty 1997: 84). In at least half the cases, the Court found some form of breach of the ECHR. United Kingdom legislation was found wanting, and in many cases the citizen was left with no redress. The political demand for incorporation of the Convention grew steadily, at first through pressure groups, and then, in the 1980s, through prominent lawyers, notably Lord Scarman, a serving Law Lord at the time, who argued for incorporation of the ECHR in a modern Bill of Rights. In the past five years, senior serving members of the judiciary have added their voices in approval.

The resulting Human Rights Act for the first time allows British citizens to use domestic courts to enforce Convention rights. British law is entering a period of considerable uncertainty as the transition to a rights-based culture is undertaken through cases decided by the judges. Intensive preparations were made for the Act's coming into force in England and Wales and an extra $£ 60$ million allocated for legal aid and court costs. The judiciary at all 
levels, from magistrates' courts to the appeals courts, were given intensive education and training programmes. A central issue is the extent of the application of Convention rights and the implications of a rights-based culture in English law. The courts have the difficult task of interpreting the proper procedures and merits of administrative decisions. So now is an opportune moment to take stock of the direction a more rights-orientated public law will lead to. There are some words of caution. While conceding, as everyone must, that human rights are intrinsic to a democratic system, there is room for consideration of the boundaries of judicial power as a custodian of rights. What degree of self-regulation should be exercised by judges when they are granted such overarching powers? How should decisionmakers be advised to achieve good decisions when individual rights may serve to inhibit risk-taking and the development of sound long-term strategies?

The substance of the rights under the Convention is narrowly confined to legal rights written in the broad language of negative liberty or 'freedom from unjustified interference'. Rights included are to liberty and security (Article 5), to a fair trial (Article 6) and to no punishment without law (Article 7). There is a right to life (Article 2) and to freedom from torture (Article 3), and a prohibition against slavery and forced labour (Article 4). There are also freedoms associated with the individual in terms of religion, the right to privacy and the freedom of assembly (Articles 8-12). Such rights have been narrowly interpreted without any formal consideration of their potential impact on issues of economic, social or political significance. The 1998 Act came about through sustained pressure from the judiciary and academic writers. Despite the existence of many draft Bills of Rights (most notably those of Lord Lester), the Government delegated the drafting of the Human Rights bill to the official parliamentary draftsman. Its form was influenced by the requirements of drafting an official government bill rather than a Private Member's Bill. The latter might have resulted in a different formulation from the one favoured by the Government.

The Act is seen as a model of its kind, but distinctive in the approach taken in the incorporation of Treaty obligations when compared to the European Communities Act 1972. 
Primacy is given to the sovereignty of Parliament, as the 1998 Act falls short of allowing the courts to hold that an Act of Parliament is unconstitutional or illegal. The most the courts may do is rule on incompatibility between the 1998 Act and the legislation under review. Since the Act came into force there have been three declarations of incompatibility. It is then for Parliament, not the courts, to resolve any incompatibility. The courts are not bound by the jurisprudence of the Strasbourg Court of Human Rights, but may give effect to those decisions.

However, it is important to recognize that legal rights developed under the Human Rights Act have the potential to shift Britain's constitutional arrangements in a new direction. In October 2001 the Court of Appeal in a series of significant judgments outlined the significance of the Human Rights Act in terms of the powers of the courts to issue injunctions in matters of planning disputes. Issues of proportionality must be considered by the courts before an injunction may be exercised under the discretionary powers of the courts to issue injunctions for threatened breaches of the law. This is but one example of the importance of the rights culture's becoming an integral part of the judicial process. It makes Ewing's remark on the danger of the unelected (judges) making important decisions over the elected (ministers) the more pertinent, even if the danger he alludes to has been addressed, in part, by the self-limitations on judicial powers that the House of Lords set out in its ruling on Alconbury (2001): ' 'We now have a constitutional system in which the output of the democratic process can avoid successful challenge and possible censure only if it can pass a test of democracy developed by a group of public officials who have escaped all forms of democratic scrutiny and accountability' (Ewing 2001: 116-17).

Finally, it is clear that there is an important extra-judicial role facilitated by judges. Judges are called upon to provide the means of independently assessing facts or inquiring into accidents, government mistakes or maladministration. In Northern Ireland at the time of writing the inquiry into the events in Londonderry in 1972 ('Bloody Sunday'), under Lord Saville, a serving Law Lord, is concerned with re-examining the work of a previous inquiry held by Lord Widgery. In total it is estimated that at least a fifth of judicial time in 
the United Kingdom is involved in carrying out an inquiry function. Valuable though this may be, it brings judges into the front line of major political controversies and, in many instances, the full glare of publicity. This may be unearthing facts and attributing fault at the expense of eroding judicial independence. Society might or might not regard this as a risk worth taking if it provides an independent review of government decisions (Loughlin 2001: 41).

\section{The European dimension}

The development of the European Union (EU) is another example of how judges now appear to be at the apex of power. The European Court of Justice provides member states with a valuable means of resolving disputes resting on the ultimate decision-maker, the courts. The Court of Justice has had a considerable influence over the development of judicial thinking in the United Kingdom and also over the authority of Parliament. Parliamentary sovereignty, long held by the courts to be the bedrock of constitutional principles, appears considerably weakened in the context of what is now the EU. More significant is the realization that the English common law is now part of a shared inheritance with the civil law tradition. The two traditions have long been contrasted as 'codified' and 'uncodified', but their differences are more profound and far-reaching in terms of the cultural adjustment needed to understand both of them.

Membership of the EU creates a possible challenge to the doctrine of the sovereignty of Parliament. Traditionalists insist that the doctrine asserting that an Act of Parliament is free from being struck down by the courts would prevail in spite of Britain's membership of the EU. The traditionalist view is compelling when it is remembered that Parliament is led by the wishes of the majority of the electorate, through a government that endeavours to carry out its election manifesto. In this way parliamentary sovereignty translates into the wishes of the people, as opposed to the decisions of unelected judges. However, the issue that arises is whether the traditional view can be reconciled with EU membership. Tensions between UK and EU law inevitably lead to the 
question of which might prevail in the event of a conflict that is not resolved by Parliament or the political system, but is left to the courts to decide. One example of the need for judicial decision-making arose from a series of cases beginning in 1991 that centred around a dispute involving Spanish fishing boats operating within the United Kingdom's fishing quota. The Spanish boats formed companies and registered in the United Kingdom. The UK Merchant Shipping Act 1988 introduced various requirements such as nationality and domicile in an attempt to restrict the use of UK fishing quotas to the UK-based fishing fleet alone. The Spanish fishermen went to court in the United Kingdom and sought interim relief from the English courts restraining the application of the 1988 Act as a first step in challenging its compatibility with Community law. The supremacy of Community law, long acknowledged in the case law of the Community, appeared at odds with the doctrine of the supremacy of United Kingdom legislation. The House of Lords in a number of key decisions arising out of the dispute resolved that:

- the United Kingdom courts must give way to European Community law even if this means acknowledging that part of an Act of Parliament is incompatible with community law;

- in general the United Kingdom courts must not apply United Kingdom statutes whenever there is a potential conflict with Community law;

- the courts are required to ensure that United Kingdom law is consistent with Community law; and

- national courts are required to ensure that the government complies with the requirements of Community law, and may provide compensation in the event of any failure to do so.

It is possible to see these rulings as evolutionary as well as revolutionary. In terms of evolving principles it is clear that United Kingdom law must be held to be compatible with Community law. More revolutionary is the idea that integrating common law and civil law approaches requires the courts of the United Kingdom to be seen as part of a single unified court system. The European Court of Justice stands at the apex of judicial powers, while the House of Lords, as part of the domestic judiciary, is there to 
implement changes. There is much food for thought in the idea that, in developing the jurisprudence of the EU, the Court of Justice has taken on powers to constrain member states, and the member states are being led by the court rather than taking the lead. On that analysis, the United Kingdom has unwittingly developed a Supreme Court system, composed of the House of Lords and the European Court of Justice, with inherent jurisdiction over community law in the United Kingdom. In a pragmatic and case-bycase approach it is possible to see the beginnings of a common law shared throughout the Community (Craig 2000: 211). The impact of the Court of Justice is currently difficult to calculate in full. But it is clear that the scope of the jurisdiction of the court is sufficient to provide a coherent convergence of common law and civil law systems. This is a trend that is likely to continue and intensify as the appropriate balance between the Court of Justice and the other Community institutions is worked out as the EU evolves while it continues to expand.

\section{The wider international dimension}

At the global level the development of ad hoc international tribunals and the International Criminal Court (ICC) is part of the ongoing expansion in judicial power. The beginnings of the trend to confront war criminals through a judicial process began with the international military tribunal at Nuremberg and the Tokyo tribunal at the end of the Second World War. More recently, there has been the establishment of the international criminal tribunal for the former Yugoslavia and for Rwanda. In July 1998 the UN conference adopted the Rome Statute of the International Criminal Court and agreed to found a permanent International Criminal Court. The creation of a war crimes jurisdiction has some way to go before it is universally accepted by all countries in the world; but it is indicative of a developing role for judges.

In developing a criminal law jurisdiction the judicial approach draws on the crimes of genocide, crimes against humanity and the crime of aggression. Article 23 of part 3 
of the Statute covering the ICC incorporates the basic fundamental principles of the criminal law. A person is not criminally liable unless his conduct constitutes a crime under an existing law. This principle builds on the general principles to be found in international criminal law, which in turn reflects the Anglo-common law approach in defining judge-made law. The developing jurisprudence of the international court will undoubtedly draw on the contribution of the Anglo-American tradition, with its pragmatic and eclectic qualities of judge-made law. The extent of its jurisprudence may impact on national sovereignty and autonomy. The Pinochet case is illustrative of the problem. In the Pinochet case (2000), the panel in the House of Lords included Lord Hoffman, in a case involving the claim for sovereign immunity against extradition made by Senator Pinochet, a former Head of State (Chile). In reaching its decision, the House of Lords allowed a variety of human rights interest groups to give evidence, including Amnesty International. Lord Hoffman was chair of a Trust set up to administer funds in connection with Amnesty International. This link was sufficient to establish that Lord Hoffman fell within the category of having an interest in the case. As a result it was considered that Lord Hoffman should have been automatically disqualified from membership of the panel. The earlier decision of the House of Lords had to be set aside and a second hearing had to take place. The case is illustrative of the potential for judges to become automatically disqualified from hearing cases in which they may have an interest. There is thus a real possibility that alongside the accumulation of judicial power questions will increasingly be raised about judges and their politics (Griffith 2000: 159).

\section{Conclusions}

The foregoing analysis provides an explanation of how judicial powers have become central in many instances to the resolution of disputes involving the implementation of legal reforms in Western countries. In many instances judges command a powerful influence, offering independence, 
public acceptance and legitimacy to the decision-making process. In countries such as the United Kingdom the incremental increase in the powers of the judiciary has brought attention to the mode of judicial appointment. The increase in judicial powers has not always been commensurate with an increase in the status or protections afforded to judges. In fact judges are easily susceptible to accusations of political bias or prejudice when asked to confront policy matters or resolve the merits of a dispute involving the government of the day and the courts. The central question is how to provide the most appropriate balance between judicial and political power, especially when in many instance the judges are appointed while politicians are elected.

The judicialization of government decision-making in an attempt to 'judge-proof' decisions may have important effects on the way the legal system works. Access to legal advice is not uniformly or universally available. The more impoverished sectors of society may become excluded. Lawyers and legal solutions are often expensive, and provide greater degrees of complexity than informal systems of decision-making. The hierarchical nature of judicial power, with a focus at the senior levels of the judiciary, often distracts attention from the lower courts, which are often underfunded, poorly resourced and susceptible to problems of inefficiency or at worst corruption. This is especially the case in a number of the newer democracies and in poor countries. But great care should be taken in considering the role of judges when legal technical assistance to such countries is being formulated. Much of the politics literature on democratization views the judiciary as an essential check on executive power and crucial to the rule of law that is central to the workings of liberal democracy. However, there are alternatives to judicial decision-making: informal mechanisms for dispute resolution, the use of administrative tribunals, and the ombudsman can all provide contributions that should be specifically tailored to the needs of individual countries. As Sweet (2000: 204) so rightly concluded, 'in the end, governing with judges also means governing the judges'. The advance of judicial power is probably unprecedented, and it becomes more essential than ever to reflect closely on where the actualité of the boundaries of political and judicial power might be set. 


\section{DISCIPLINES}

\section{Notes}

1 For a recent example see the Guardian, 16 October 2002, p. 1 report, 'Woolf [Lord Woolf, Lord Chief Justice] warns government on human rights'.

2 Dr Bonham's case 77 Eng. Rep. 646 (CP 1609).

3 M v. Home Office (1992) 1 QB 270 at 314H-315A.

4 X Ltd v. Morgan-Grampian Ltd (1991) 1 AC 1.

$5 \mathrm{R}$ (on the application of Alconbury Developments Ltd) v. Secretary of State for the Environment, Transport and the Regions (2001) 2 All ER 929. 